\title{
THE FIRST ANAESTHETIC IN SOUTH AFRICA
}

by

\author{
EDMUND H. BURROWS, м.B., сн.B. (GAPE TOWN)
}

IT is generally accepted that the era of medical anaesthesia opened for the world in the Massachusetts General Hospital, Boston, in October 1846 when W. J. G. Morton (1816-68), a Boston dentist, successfully anaesthetized a patient upon whom J. C. Warren ( $1778-1856)$ performed a painless operation. One of the spectators was the eminent American surgeon $\mathrm{H}$. J. Bigelow (1818-90). Whilst Morton's claim to be the discoverer of anaesthesia cannot be substantiated, he must be honoured for acquainting the medical profession with the anaesthetic properties of sulphuric ether, for as a direct result of his demonstration the substance was adopted throughout the civilized western world.

News of the operation spread with remarkable rapidity. By mid-December London knew of it, and in the first number at the new year The Lancet published Professor Bigelow's letter (written on 28 November 1846) to Francis Boott in London. In the same issue Robert Liston (1794-1847), Professor of Clinical Surgery in the University of London, recommended its use to the profession. ${ }^{1}$ By that date both men had used it, for Boott had extracted a tooth under anaesthesia on 19 December, and two days later Liston performed his celebrated thigh amputation at University College Hospital. ${ }^{2}$ By February 1847 English publications were reporting anaesthetic operations and describing apparatus for administering ether, and it had already been used in most continental countries. Four months later the news was at the Cape of Good Hope, and on 16 June a diseased leg was painlessly amputated with its aid in Grahamstown.

\section{THE GAPE OF GOOD HOPE}

For centuries the Cape of Good Hope was the mariner's half-way house between Europe and the Orient. The sole purpose of the original Dutch settlement in Table Bay in 1652 had been to provide fresh water and vegetables for the merchant fleets and to rid them of their scurvy-ridden sailors. For two centuries-in fact, until the opening of the Suez Canal in 1869-the Cape had no other value to its European masters, successively Holland and England, and it was administered solely as an outwork of the Indian empires of these powers. The economy of the Cape Colony might well have collapsed after diversion of the Indian traffic through Suez, had not diamonds been discovered in 1867 near present-day Kimberley-an event that heralded the development of modern South Africa. The Colony's agricultural economy was suddenly diverted from supplying the needs of Table Bay shipping to maintaining the diamond fields 


\section{Edmund H. Burrows}

inland. Cape Town remained fons et origo, the only large settlement in the Colony, apart from the village of Grahamstown in the eastern province, where 4,000 British immigrants had settled in 1820 .

In 1847 Cape Town was approaching its bi-centenary, still a welcome haven in the eyes of the maritime world, and now a popular recuperating ground for Indian civil service officials and army officers as well. It had a population of probably 50,000 whites, mostly the wealthy descendants of the Dutch burghers, and as many coloured people. Professionally Cape Town was served by about forty practitioners, all of whom were licensed for practice by the Colonial Medical Committee, a statutory body that examined and approved the credentials of all aspirant practitioners. The effect of this control was to eliminate the quacks and to enhance the status of the medical fraternity in the Colony. Half the licensed practitioners were Cape-born men that had qualified in Europe (mostly at the University of Leyden in the Netherlands) and the remainder were regularly trained English and continental surgeons. Professional esprit de corps had sustained a medical society for twenty years, and in 1847 two young practitioners published the first South African medical journal, the Cape Town Medical Gazette. This ambitious project collapsed soon after its commencement, after four numbers had appeared. The focal-point of this virile medical community was the Somerset Hospital, a civil institution erected in 1817 to replace the old maritime Ziekenhuis of the Dutch East India Company, where a variety of surgical procedures, including amputations, was performed. Frequently medical practitioners dropped in to watch operations, and the surgeon to the hospital, Henry Bickersteth (1813-62), published his case reports in the local Gazette.

\section{DR. WILLIAM GUYBON ATHERSTONE}

At the other end of the Colony in Grahamstown, medical affairs revolved around the personality of Dr. William Guybon Atherstone (1814-98), a student of the Universities of Dublin and Heidelberg and one of the first Fellows of the Royal College of Surgeons in South Africa, who was one of the Cape's great scientists. Grahamstown was small, but it was the cultural capital of the eastern province and (for some years) the headquarters of the Imperial Army establishment at the Gape. A military hospital had been built in 1845 , and thereafter four or five regimental surgeons were stationed there permanently. But the heart of Grahamstown was Dr. Atherstone himself. William Guybon Atherstone remains a dominating personality in the history of English-speaking South Africa. The son of an 1820 settler surgeon, he had been taken to the Cape from Nottingham at an early age and had seen service in a native war before he returned to Europe to complete his medical studies. When he was appointed district surgeon of Grahamstown he became a landmark in the Colony, for there was not a facet of settler life that he did not enrich and almost no branch of science to which he did not contribute. He has been called 'the Father of South African Geology', and for his original work he was elected a Fellow of the Geological Society of London. It was he that pronounced the first 


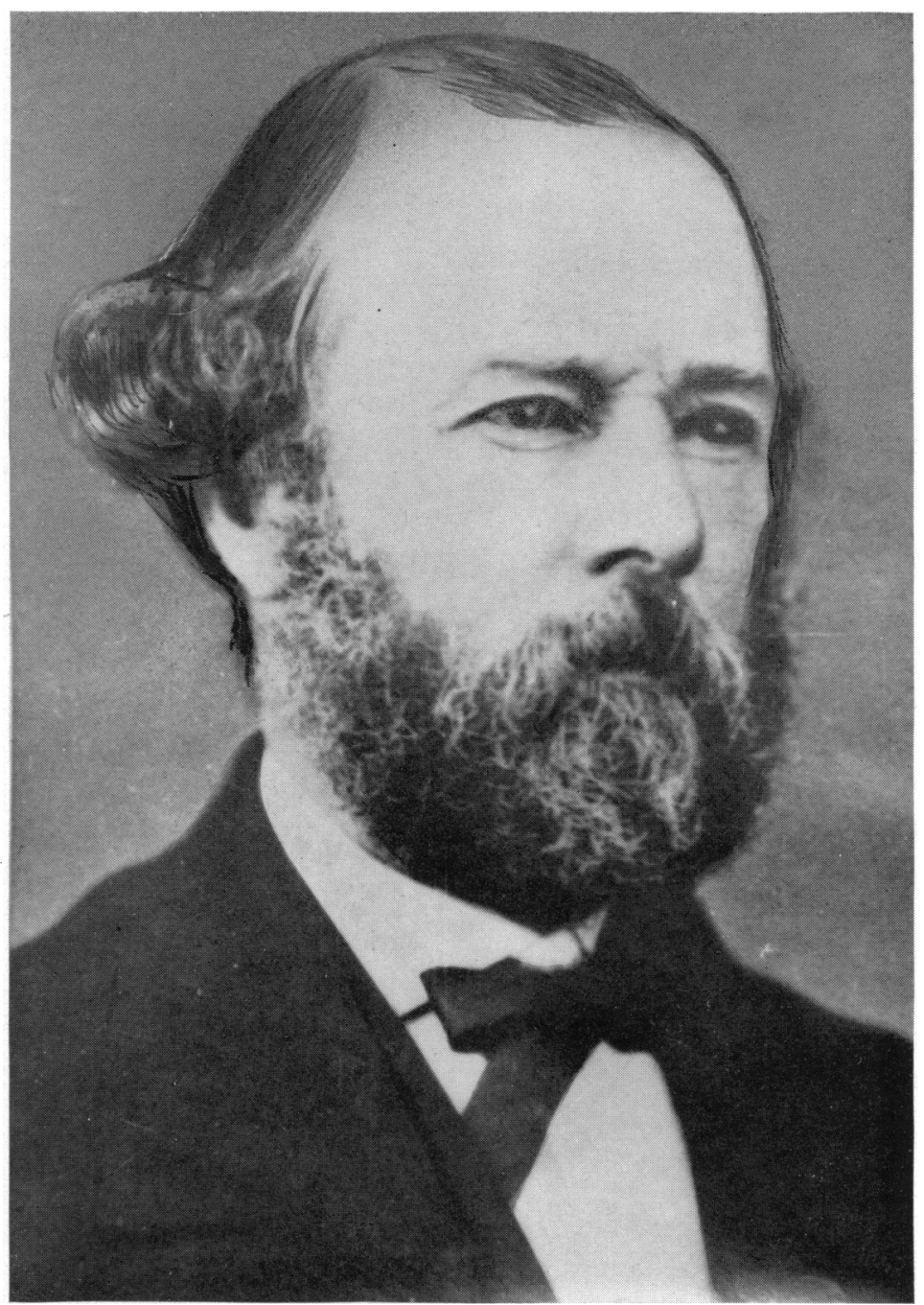

Fig. I

DR. WILLIAM GUYBON ATHERSTONE

(I8I4-I898). 

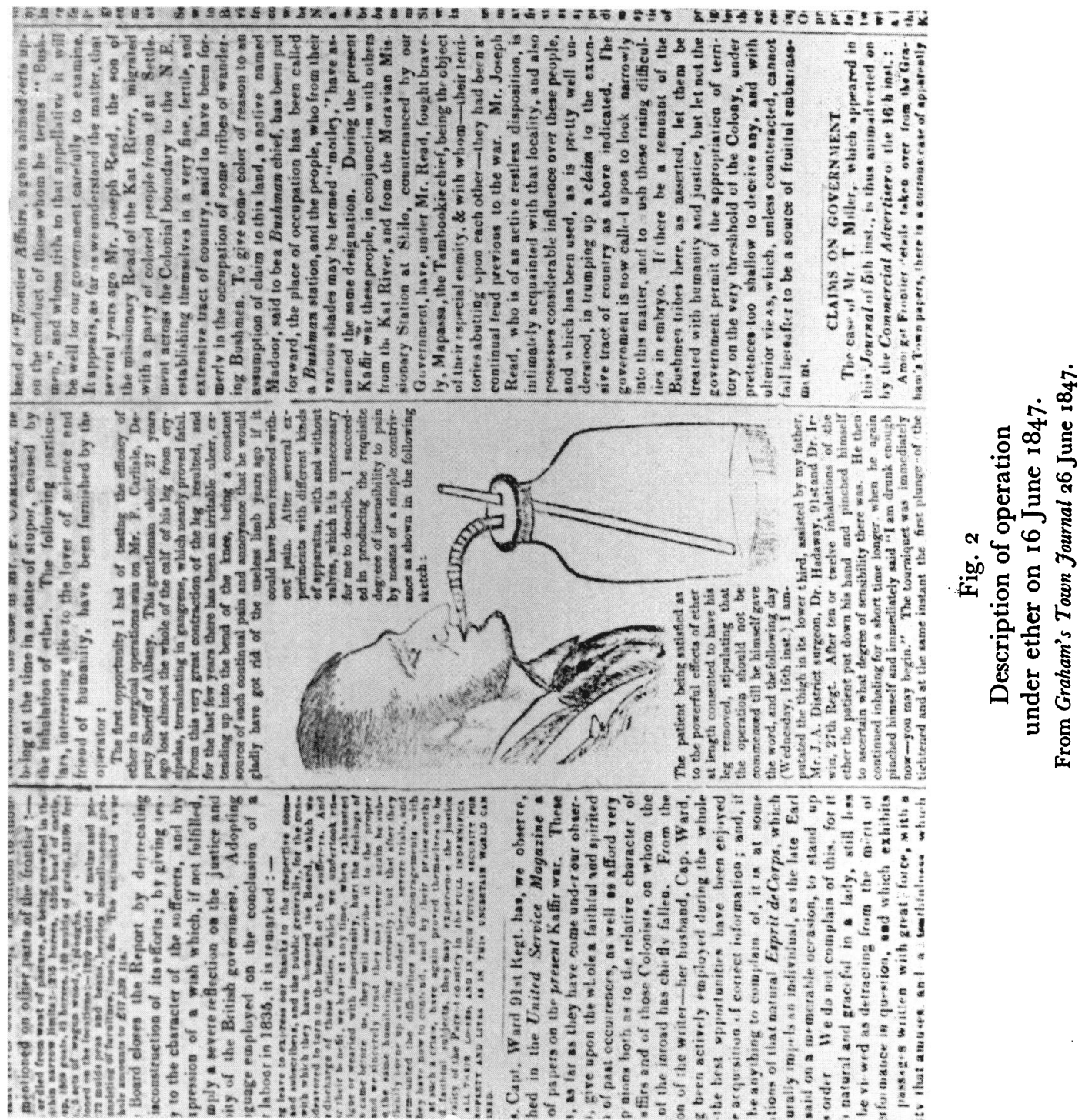


\section{The First Anaesthetic in South Africa}

stone from the present Kimberley area to be a true diamond, and it was he who predicted the vast mineral resources of the Transvaal. He was an anthropologist, and there is a saurian, called Tapinocephalus atherstonii by Sir Richard Owen, in the British Museum. He was a fair artist, a musician, an astronomer and a keen botanist, and there was not a public committee in Grahamstown, and indeed the eastern province, upon which he did not serve. He was responsible for the first faltering steps taken in medical legislation in South Africa, and played a great role in the establishment of Colonial medical institutions. And, withal, he was a doctor.

The news of the Massachusetts operation reached the Cape direct from

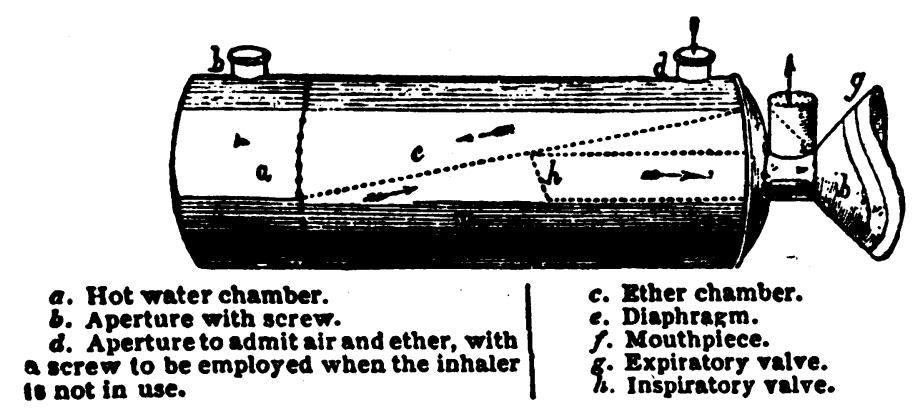

Fig. 3

Smee's ether inhaler.

From Pharm. 7. \& Trans., 1846-7, 6, 425 .

America by sailing vessel early in 1847 . (A flourishing slave traffic was then carried on between the east coast of Africa and North America.) The report that reached Grahamstown contained no details of Morton's method of administering the ether. Moreover, Dr. Atherstone appears to have been, at that time, completely unaware of the London trials carried out earlier in 1847. To judge from his reminiscences at a medical congress fifty years later (when his powers were already failing and he was totally blind), he knew no more than the bare fact that a painless amputation had been performed through the continuous inhalation of sulphuric ether by the patient. ${ }^{3}$ In 1846 he had himself relieved the spasms of a severe case of tetanus by three-hourly 'feeds' of Cape brandy, and saved a life, so we know that he did not shrink from intelligent experimentation. Moreover, he had good reasons to investigate Morton's claims for sulphuric ether. The deputy sheriff of the district, Frederick Carlisle, had lost part of a leg from erysipelas which terminated in gangrene some twenty-seven years previously, and an indolent ulcer had developed in the flexion contracture at the knee. Carlisle was keen to be rid of the useless limb, but he dreaded the amputation. The report from America was as welcome to him as it no doubt was to Dr. Atherstone. 


\section{Edmund H. Burrows}

\section{THE FAMOUS AMPUTATION}

After several experiments with different kinds of apparatus, with and without valves [he reminisced years later], I succeeded in producing the requisite degree of insensibility to pain by means of a simple contrivance somewhat resembling the Turkish narghili or hubble-bubble in principle. It consisted of a large wide-mouthed bottle, capable of holding two quarts, and the cork had two holes through it. Into one of these a glass tube was fitted, which extended to within a quarter of an inch of the surface of the ether. In the other hole an elastic tube with an ivory mouthpiece was fixed, for inhaling the vapour. About half an ounce of ether having been poured down the glass tube, both tubes were stopped for some minutes to allow the bottle to fill with vapour before inhaling. Then, everything being properly prepared, I got Mr. Carlisle's consent, and, assisted by my father, Mr. John Atherstone, District Surgeon, Dr. Hadaway, 91st Regiment, and Dr. Irwin, 27th Regiment, I amputated his thigh in its lower third on Wednesday, the 16 th June, $1847 .^{4}$

In the Graham's Town Fournal of 26 June 1847 Dr. Atherstone described the operation in detail.

After ten or twelve inhalations of the ether the patient put down his hand and pinched himself to ascertain what degree of sensibility there was. He then continued inhaling for a short time longer, when he again pinched himself and immediately said: 'I am drunk enough now -you may begin.' The tourniquet was immediately tightened and at the same instant the first plunge of the knife effected without the least motion or sign of suffering on the part of the patient, who at this stage appeared perfectly unconscious, and continued inhaling the ether, mechanically opening and closing his nostrils with his own hand. So perfect was the insensibility that Dr. Irwin, who had placed his hand on the patient's arm, thinking he might start, finding not the slightest resistance during the first incision, removed his hand altogether, as did also an assistant who had taken hold of the leg, and for the rest of the operation the patient lay perfectly free and motionless on the bed. At the second incision, which divided the large nerves and vessels, he uttered an involuntary shriek, although not the slightest movement was perceptible or other symptoms of pain. As soon as the leg was off the bottle was removed, the patient still holding his nose and becoming talkative and even humourous as he gradually recovered from the stupefying effects of the ether. The time during which the ether was inhaled was about three minutes.

When the arteries were taken up and the dressing being applied, the following dialogue took place between the patient and one of the medical men present:

Patient: It's very odd, do you know I fancy I am still holding my nose!

Dr. I.: Well, so you are, most energetically too!

Patient: Then why remove the vapour?

Dr. I.: Because the operation is all over-your leg has been taken off some time now.

Patient: Now don't talk nonsense to me-I'm a reasonable man you know-explain to me why the bottle is gone.

Dr. I.: You don't want it any longer-your leg is off, Mr. Carlisle!

Patient: What? My leg off? Impossible-I can't believe it-let me see for myself. (And on seeing the stump he burst out:) God be praised! It's the greatest discovery ever made! We must erect a monument to this fellow's memory. It's the greatest boon ever conferred on man. I have been totally unconscious of everything-the sound of that horrid saw still grates upon my ear as if in a dream from which you have just awoke me, but as for pain I have not felt the slightest.

At the annual congress of the South African Medical Association in Grahamstown in 1896 the local branch presented a paper entitled 'Anaesthesia', 'since this (year) is the Jubilee of Anaesthesia and Dr. Atherstone having been the first to administer Anaesthetics in this Colony'.5 And Dr. Atherstone himself 


\section{The First Anaesthetic in South Africa}

stated on this occasion, referring to his celebrated use of ether a half-century previously: 'This was its first use outside of America and Europe.' On the strength of this evidence, the South African Historical Monuments Commission has recently erected in the house from which Dr. Atherstone conducted his practice in Grahamstown, and where, it is presumed, the operation was performed, a plaque commemorating the event.

\section{GAPE TOWN EXPERIMENTS}

Meanwhile reports of the progress in ether anaesthesia made in London had reached the medical fraternity in Cape Town. Sailing ships took one hundred days to the Cape and steamships slightly less, so that news of the University College Hospital amputation would have reached the Cape by April, when the 'early trials' are known to have commenced in Cape Town. ${ }^{6} \mathrm{~A}$ bullock's bladder fitted with a sponge mouthpiece and distended with air and about I fl. oz. of ether was used in the first experiment. The patient's nostrils were compressed during inspiration. In 'later trials'-also reported in the July number of the Cape Town Medical Gazette-reference is made to Smee's apparatus, which was felt to have only the advantage of comfort over the bullock's bladder. Alfred Smee had described his valved ether container with flanged mouthpiece (see Fig. 3) in the February 1846 number of a London journal which would probably have reached the eyes of the Cape physicians or pharmacists. ${ }^{7}$ In the interval between arrival of the journal in Cape Town (about April or May 1847) and publication of the Gazette in July, a model of Smee's apparatus was procured from London or-what is more likely-a replica of the apparatus was manufactured locally by a Cape tinsmith. At any event, Smee's apparatus was used in Cape Town within six months of its introduction in London. And the local Gazette could report that the local trials had shown '(ether) to be an effectual mode of producing perfect insensibility to pain'.

Towards the end of July - a clear month after Dr. Atherstone's amputationtwo below-knee amputations under general anaesthesia were performed in Cape Town. ${ }^{8}$ 'In the first the patient, a woman of about fifty-five years of age, was but partially under the influence of the ether when the first incision was made. She afterwards declared that the sound of the saw passing through her bones gave her the first intimation of the operation having been commenced . . . this case has done remarkably well.' The second case was not so successful. While no names are mentioned, the articles appeared as editorial matter in the Gazette, so that one can perhaps assume that at least one of the two young editors-both were still in their twenties-was involved in the trials. H. A. Ebden (1824-86) was the son of an English merchant in Gape Town and had graduated M.D. at St. Andrew's in I845, whilst F. le Sueur Fleck (182 I-5I) was a member of one of the patrician families of the Colony. It is also possible that the amputations were performed by Henry Bickersteth at the Somerset Hospital.

A brief announcement in a Cape Town newspaper in $185^{\circ}$ describes the first 


\section{Edmund H. Burrows}

known use of chloroform at the Cape for the purpose of general anaesthesia. It described the disarticulation of the arm of a young girl in the shoulder-joint by Dr. F. L. G. Biccard (1809-84): 'The patient inhaled the wonderful article from the hands of Dr. Biccard (the Sir Astley Cooper of the Gape) and during the separation felt no pain. She has perfectly recovered.' 9 Biccard was one of the select band of Cape students that studied at Leyden University, and the author of a medical vade mecum for Cape households-one of the earliest medical books published in South Africa.

\section{REFERENCES}

I. Lancet, $1847, \mathrm{I}, 5,8$.

2. Horine, E. F. (1946), 7. Hist. Med., I, 521 .

3. Atherstone, W. G. (1897), S. Afr. med. J., rv, 246.

4. Atherstone, W. G. (1897), ibid., Iv, 245.

5. Minutes of the Eastern Medical Association, Grahamstown. Entry on 20 November 1896.

6. Cape Town med. Gaz., July r847. (Editorial.)

7. Pharm. 7. $\&$ Trans., 1846-7, vi, 425 .

8. Cape Town med. Gaz., October 1847 . (Editorial.)

9. African Fournal (Cape Town), 20 June 1850. 